single homeless must be matched by adequate resources for their primary health care. Furthermore, public, professionals, and politicians must recognise more widely the social changes needed to tackle homelessness at source.

P V POWELL

Community Medicine Specialist,

Lothian Health Board,

Edinburgh EH3 7QQ

1 Drake M, O'Brien M, Biebuyk T. Single homeless. London: HMSO, 1981.

2 Digby PW. Hostels and lodging houses for single people. London: HMSO, 1976.

3 Alstrom CH, Lindelius R, Salum I. Mortality among homeless men. Br J Addict 1975;70:245-52.

4 Priest RG. The Edinburgh homeless-a psychiatric survey. Am $\mathcal{Y}$ Psychother 1971;25:194-213.

5 Hewetson J. Homeless people as an at-risk group. Proc $R$ Soc Med 1975;68:9-13.

6 Scott R, Gaskell PG, Morrell DC. Patients who reside in common lodging houses. Br Med $\mathcal{J}$ 1966;ii:1561-4.
7 Shanks NJ. Medical provision for the single homeless in Manchester. $f \mathrm{R}$ Coll Gen Pract

8 Powell PV. A 'house doctor' scheme for primary health care for the single homeless in Edinburgh J R Coll Gen Pract 1987;37:444-7.

9 Bayliss E, Logan P. Primary health care for homeless single people in London: a strategic approach. London: Single Homeless Inner London Health Sub-group, 1987.

10 Davison AG. Use and misuse of an Accident and Emergency Department in the the East End of London. F R Soc Med 1983;76:37-40.

11 Powell PV. The use of an accident and emergency department by the single homeless. Health Bull 1987; 45:255-62.

12 McLean U, Naumann L. Primary medical care for the single homeless: the Edinburgh experiment. Health Bull 1979;37:6-10.

13 El Kabir DJ. Gt Chapel St Medical Centre. Br Med f 1982;285:446-8.

14 Wylie I. Wytham Hall annual report. London: Wytham Hall, 1985.

14 Wylie I. Wytham Hall annual repont. London. Wytham Hall, 1985.

15 Anonymous. Pay GPs more for their work. Pulse 1987 Oct 11:19.

Cumberledge J. Neighbourhood nursing - a focus for care. Report of the community nursing review. London: HMSO, 1986.

17 Elton P. Manchester and Salford health care for homeless people project-interim report. Manchester: Manchester and Salford Health Authorities, 1985.

18 Office of Population Censuses and Surveys. Morbidity studies from general practice. Second national study. London: HMSO, 1974.

19 Powell PV. Qualitative assessment in the evaluation of the Edinburgh primary health care scheme for single homeless hostel dwellers. Community Medicine (in press).

\title{
Submucous cleft palate
}

\section{A treatable condition that is commonly missed}

Although submucous cleft palate was first described in 1825 , it remains a diagnosis that is missed or forgotten by many nonspecialists. ${ }^{2}$ Yet it occurs in about one in 1200 births, ${ }^{2}{ }^{3}$ and $4 \%$ of attendance at clinics for patients with cleft lip and palate are for the condition. ${ }^{4}$ Submucous cleft palate is an abnormality of the muscle attachments to the soft palate with an intact oral and nasal mucosa. ${ }^{56}$ Feeding difficulties, speech problems, and disease of the middle ear may result because of the abnormal muscle attachments to the palate and eustachian tubes, but about $10 \%$ of cases are symptomatic. ${ }^{3}$

Kelly first described the classical triad of signs of submucous cleft palate: a translucent zone in the midline of the soft palate, a bifid uvula, and a notched posterior nasal spine on palpation. ${ }^{7}$ Not all these features must be present for the condition to be diagnosed, ${ }^{48}$ and a bifid uvula occurs in isolation in about $0 \cdot 1-3 \%$ of normal people. ${ }^{269}$

A review of over 80 cases of submucous cleft palate showed that 22 of the 26 infants in the review showed slowness to feed (taking longer than 40 minutes), together with nasal regurgitation for which no other cause was found (A L H Moss et al, meeting of the British Cranofacial Society, Edinburgh, 1987). The incidence of these feeding problems in the normal population is not known, but submucous cleft palate must be included in the differential diagnosis of these symptoms. The incidence of disease of the middle ear in this group of patients is probably similar to that in patients with overt cleft palate-that is, $59-93 \% .^{610-12}$

The review showed that patients with submucous cleft palate had three main patterns of presentation (A L Moss et al, meeting of the British Cranofacial Society, Edinburgh, 1987). Firstly, those under 12 months all had feeding difficulties (slowness and nasal regurgitation). The second group all had speech problems with velopharyngeal incompetence (nasal escape and hypernasal resonance), and most had related faults of articulation. These patients were aged $21 / 2$ to 10 years, and most had been referred by ear, nose, and throat surgeons or speech therapists. Just over half of the group also had symptomatic chronic secretory otitis media that needed treatment. The third group comprised a diffuse collection of patients (all over 10 but only four over 20) referred from various sources, including general practitioners, psychiatrists, school medical officers, and oral surgeons. All showed abnormalities of speech.

A quarter of those over $2 \frac{1}{2} 2$ years had had an adenoidectomy, a procedure long contraindicated in patients with submucous cleft palate. ${ }^{113}$ The middle ear symptoms in these children are more likely to be caused by the abnormality of muscle attachment that results in dysfunction of the eustachian tube than by the adenoids themselves. ${ }^{514-16}$ The incidence of velopharyngeal incompetence after adenoidectomy is about one in 1400 cases but may be more common..$^{131516}$

Several techniques have been described to help confirm the diagnosis of submucous cleft palate, but the most reliable is videofluoroscopy with barium contrast and nasopharyngoscopy. ${ }^{6}{ }^{17}$ The classical and characteristic appearance is of a ridge or valley on the nasal aspect of the soft palate caused by the abnormal position and attachments of the muscles, particularly of the musculus uvulae. ${ }^{5}$ The investigation will define whether pharyngeal disproportion coexists and indicate whether pharyngoplasty is needed as well as repair of the palate. ${ }^{1718}$ When the patient has symptoms the palate should be explored and the levator sling reconstructed, ${ }^{8}$ and the earlier the child is treated the better their speech. ${ }^{219}$

In conclusion, newborn infants should be examined intraorally both visually and with the finger. Any feeding difficulties without an obvious cause should alert the paediatrician, general practitioner, midwife, or health visitor of the possibility of submucous cleft palate. An early referral to a paediatric otologist will allow the function of the middle ear to be fully assessed and the problems to be treated. Speech can be assessed accurately by $2 \frac{1}{2}$ years; nasal escape may sometimes be picked up earlier by experienced speech therapists. ${ }^{212}$ Because of the high incidence of asymptomatic submucous cleft palate an operation is not justifiable after diagnosis at birth, but close supervision should allow the decision to be taken by about $2 \frac{1}{2} 2$ years, when the results of repair should be excellent. ${ }^{2}$

A L H MOSS

Senior Registrar in Reconstructive Plastic Surgery $\mathrm{R}$ W PIGGOTT Consultant in Reconstructive Plastic Surgery $\mathrm{K} J$ JONES

Frenchay Hospital, Senior Speech Therapist

Bristol BS16 ILE

1 Roux JP. Memoires sur la staphylorraphie, ou suture du voile du palais. Paris: I S Chaude, 1825

2 Weatherley-White RCA. Submucous cleft palate. In: Calnan J, ed. Recent advances in plastic surgery. Edinburgh: Churchill Livingstone, 1976:58-67.

3 Weatherley-White RCA, Sakura CY, Brenner LD, Stewart JM, Ott JE. Submucous cleft palate. Plast Reconstr Surg 1972;49:297-304.

4 Crikelair GF, Striker P, Cosman B. The surgical treatment of submucous cleft palate. Plast Reconstr Surg 1970;45:58-65. 
5 Kaplan EN. The occult submucous cleft palate. Cleft Palate 7 1975;12:356-68.

6 Shprintzen RJ, Schwartz RH, Daniller A, Hoch L. Morphologic significance of bifid uvula Pediatrics 1975;75:553-61.

7 Kelly AB. Congenital insufficiency of the palate. Journal of Laryngology, Rhinology and Otolog 1910;25:281-358.

8 Trier WC. Velopharyngeal incompetency in the absence of overt cleft palate: anatomic and surgical considerations. Cleft Pulate 7 1983:20:209-17.

9 Beeden AG. The bifid uvula. 7 Laryngol Otol 1972;86:815-9.

10 Stool SE, Randall P. Unexpected ear disease in infants with cleft palate. Cleft Palate $\mathcal{F}$ 1967; 99-103.

11 Bergstrom L, Hemenway W. Otologic problems in submucous cleft palate. South Med $\mathcal{J}$ $1971 ; 64: 1172-8$
12 Heller JC, Gens GW, Croft CB, Moe DG. Conductive hearing loss in patients with velopharyngeal insufficiency. Cleft Palate J 1972;15:246-53.

13 Calnan J. Submucous cleft palate. Br I Plast Surg 1954;6:264-82.

14 Kriens OB. Fundamental anatomic findings for an intravelar veloplasty. Cleft Palate $\mathcal{X} 1969 ; 6$ : 27-36.

15 Croft CB, Shprintzen RJ, Ruben RJ. Hypernasal speech following adenotonsillectomy. Otolaryngol Head Neck Surg 1981;89:179-88.

16 Witzel MA, Rich RH, Margar-Bacal F, Cox C. Velopharyngeal insufficiency after adenoidectomy: an 8-year review. Inı $\mathcal{F}$ Pediatr Otorhinolaryngol 1986;11:15-20.

17 Moss ALH, Pigott RW, Albery EH. Hynes pharyngoplasty revisited. Plast Reconstr Surg 1987;79:346-53

18 Pigott RW. Objectives for cleft palate repair. Ann Plast Surg 1987;19:247-59.

19 Porterfield HW, Trabue JC. Submucous cleft palate. Plast Reconstr Surg 1965;35:45-50.

\section{Regular Review}

\section{Prospects for vaccines against HIV}

\section{$A$ vaccine for routine use is at least five to 10 years away}

The best and cheapest method of preventing illness is immunisation, and we urgently need effective vaccines against the human immunodeficiency virus (HIV). This enormous undertaking will be facilitated by the rapid advances in molecular biology and recombinant DNA technology, the understanding of immunological mechanisms, and the production and application of monoclonal antibodies so that the structure and location of important antigenic epitopes may be determined. Chemical synthesis of oligopeptides has been simplified, and computer programs, $x$ ray crystallography, and other methods provide the tools for determining the three dimensional structure of proteins so that the structure and location of antigens or epitopes may be predicted. These techniques have already led to novel vaccines against hepatitis $B$ virus and the virus causing foot and mouth disease. ${ }^{1-5}$

HIV is placed taxonomically in the lentivirus group, a subfamily of the retroviruses. This virus encodes DNA synthesis directed by ribonucleic acid (RNA) (reverse transcription). The enzyme reverse transcriptase catalyses synthesis from the single stranded RNA of the virus of a double stranded DNA intermediate, the provirus, which becomes integrated into the host DNA and serves as a template for viral genomic and messenger RNA transcription by the host cell.

The development of vaccines against HIV is beset with difficulties because of the nature of the virus and because antibodies to the structural components of the virus (figure) are present in infected people, often at a high titre, although such humoral antibodies may be protective before the onset of infection; in addition, the surface lipoprotein envelope of the virus is subject to variation; and there is a lack of suitable small laboratory animals that are susceptible to this infection.

\section{Inactivated virus vaccines}

Traditionally vaccines against virus infections are based on inactivated or killed whole virus preparations-for example, the influenza vaccine and the Salk (killed) poliovirus vaccine -or its surface antigen component-for example, the plasma derived hepatitis B surface antigen vaccine. This approach, however, presents several problems. HIV will have to be grown in large amounts under conditions of high and secure containment. Complete inactivation of the virus without loss of antigenicity and immunogenicity must be assured-a difficult task without small animal models. The use of cell culture systems for this purpose raises the difficulty of inserting viral nucleic acids into the host cell chromosome and encouraging the production of new and infectious viruses. ${ }^{6}$

Immunisation and vaccination after infection against two animal lentiviruses have led to severe clinical syndromes on subsequent exposure to live virus-for example, goats

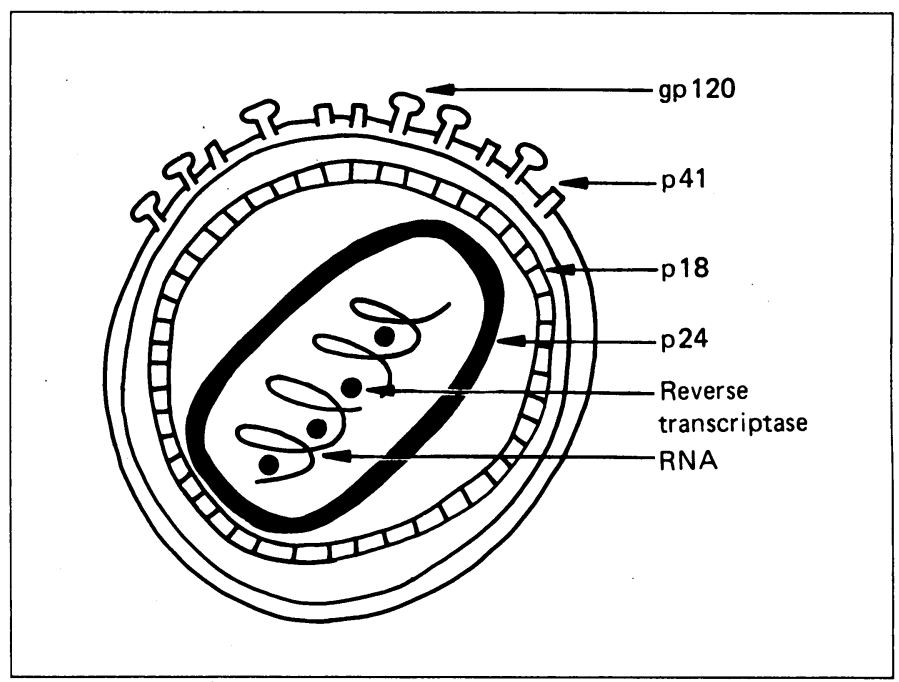

Anatomy of HIV (after Dr H Gelderblom). The virus particle consists of a lipid bilayer in which the envelope protein is incorporated with the transmembrane pedicle $(g p 41)$ and the protruding knoblike structures ( $g p$ 120). The core, which contains the RNA genome and reverse transcriptase, is surrounded by two membranes - an outer layer (p18) and an inner membrane ( $p 24)$

inoculated with inactivated preparations of the virus causing carpine arthritis and encephalitis develop a more severe disease when challenged with live virus. Caution will therefore be required in developing and testing such vaccines against HIV. ${ }^{7}$ An additional problem is that inactivated HIV vaccines may induce immunosuppression if by analogy with animal retroviruses this syndrome is induced by a viral component.

\section{Attenuated live virus vaccines}

Using live virus vaccines against HIV is precluded by many of the considerations that make inactivated virus vaccines difficult. The construction in vitro of a non-pathogenic virus by gene deletion seems an attractive option, but this approach has several disadvantages. Firstly, reverse transcription of the viral genome into copies of DNA and integration into the cellular genome may occur. Secondly, recombination with endogenous retroviral sequences may restore pathogenicity. 